\title{
Characterizations of the Antimicrobial Resistant Determinants in Proteus spp. Isolated from Humans and Chickens in the Chungcheong Province
}

Ji Youn Sung

Department of Biomedical Laboratory Science, Far East University, Eumseong 27601, Korea

\section{충청지역의 사람과 닭으로부터 분리된 Proteus속에 속하는 균주에 존재하는 항균제 내성유전자의 유전형 분석}

성지연

극동대학교 임상병리학과

Recently, antimicrobial resistance of pathogenic bacteria has been increasing due to excessive use of antimicrobial agents in both humans and livestock. PCR amplification and nucleotide sequence analyses were conducted to investigate16S ribosomal RNA methyltransferase (RMTase) genes and integrons in $P$. mirabilis strains isolated from clinical specimens and chickens in an area of the Chungcheong providence. In addition, clonality analysis of $P$. mirabilis strains was performed using a repetitive extragenic palindromic sequence-based PCR (REP-PCR) method. Of the total $38 P$. mirabilis isolates, 7 (18.4\%) strains were isolated from clinical specimens contained in the RMTase genes and showed resistance to amikacin, tobramycin, and gentamicin. A total of 23 (60.5\%) isolates carried class 1 integrons, but no isolates in our study harbored class 2 and class 3 integrons. Class 1 integrons detected in our study harbored genes encoding resistance to aminoglycosides (aadA2, aadA5, aadA7, and aacCA5), $\beta$-lactams (blapse), erythromycin (ere $A$ ), lincosamides (linf), and trimethoprim (dfrA12, dfrA17, and dfrA32). We confirmed that the RMTase genes had spread among only the $P$. mirabilis isolates from clinical specimens, but class 1 integrons had widely disseminated among $P$. mirabilis isolates from clinical specimens and chickens. In addition, identical REP-PCR banding patterns were evidenced in only $P$. mirabilis isolates from chickens. Our results suggest the horizontal spreading of $P$. mirabilis isolates in the chicken farm. To prevent further spreading of antimicrobial resistant genes among $P$. mirabilis isolates, monitoring and clinical policing will be required.

Key words: $16 \mathrm{~S}$ ribosomal RNA methyltransferase, Integrons, Chickens, P. mirabilis

This is an Open Access article distributed under the terms of the Creative Commons Attribution Non-Commercial License (http://creativecommons.org/licenses/by-nc/4.0) which permits unrestricted non-commercial use, distribution, and reproduction in any medium, provided the original work is properly cited

Copyright @ 2016 The Korean Society for Clinical Laboratory Science. All rights reserved.
Corresponding author: Ji Youn Sung Department of Biomedical Laboratory Science, Far East University, Wangjang-ri, Gamgok-myeon, Eumseong 27601, Korea Tel: 82-43-879-3668 Fax: 82-43-880-3876 E-mail: azaza72@naver.com

Received: October 28, 2016 Revised $1^{\text {st: }}$ November 17,2016 Revised 2 ${ }^{\text {nd. }}$ : November 20, 2016 Accepted: November 20, 2016
서 론

최근 사람과 가축에 항균제의 과도한 사용으로 감염병을 일으키 는 병원성 세균들의 항균제 내성이 증가하여 세균에 의한 감염병의
항균제 치료가 더욱 어려워지게 되었다. 특히 가축의 생산성을 높 이기 위해 많은 양의 항균제가 지속적으로 사용되어왔는데 이러한 항균제의 사용은 항균제를 직접 투여 받은 가축은 물론 사람, 식료 품, 및 주변환경에 내성세균을 확산시키는 결과를 낳았다[1]. 충청 
지역의 가축에서 분리된 세균들의 경우 aminoglycoside계열 항균 제인 gentamycin을 포함한 여러 계열의 항균제에 높은 내성을 보 였으며 서로 다른 두 계열의 항균제를 지속적으로 가축에 사용해 온 경우 다제내성 세균의 발생빈도가 높았다고 하였다[2].

Aminoglycoside계열 항균제는 대부분의 그람음성세균과 일부 그람양성세균에 의한 감염증 치료를 위해 사용되어 왔다[3]. 그러 나 다양한 세균들이 이미 aminoglycoside계열 항균제에 자연내성 을 가지고 있거나 내성에 관여하는 유전자를 획득함으로써 항균제 에 내성을 보여왔다. Aminoglycoside계열 항균제가 투여되면 세 균의 세포벽은 aminoglycoside계열 항균제와 같이 작은 분자가 세균세포 안으로 들어오지 못하도록 장벽역할을 하는데 관련유전 자에 변이가 있을 경우 장벽은 더욱 견고하게 작동되어 내성을 유 발한다. 일단 세균세포 안으로 들어온 aminoglycoside계열 항균 제는 유출펌프의 작용에 의해 세균세포 바깥으로 내보내지게 되는 데 유출펌프의 유전자에 변이가 생겨 그 기능이 증폭될 경우 세균 은 더욱 강력한 내성을 나타내게 된다. 한편 세균은 항균제의 표적 이 되는 리보좀에 변이가 생기거나 aminoglycoside계열 항균제 자체가 여러 수식효소에 의해 변형이 되는 경우에도 항균제에 내성 을 나타낸다. 이러한 aminoglycoside계열 항균제 내성기전 중 가 장 임상적으로 문제가 되는 것은 $16 \mathrm{~S}$ ribosomal RNA methyltransferases (RMTases)에 의한 리보좀 변이로 RMTases (armA, $r m t A, r m t B, r m t C, r m t D$, 및 $n p m A)$ 는 대부분의 aminoglycoside 계열 항균제에 내성을 유발한다. 게다가 mobile genetic element 를 통해 빠르게 확산될 수 있어 더 큰 문제가 되고 있다[3,4]. Mobile genetic element 중 특히 integron은 장소특이적 재조합에 의해 외래유전자 카세트를 획득하고 발현시킬 수 있어 항균제 내성유전 자의 확산에 매우 중요한 역할을 한다[5].

최근까지 aminoglycoside계열 항균제에 대한 내성연구가 많이 진행되었고 보고되고 있으나 주로 사람에서 분리된 세균을 대상으 로 이루어졌으며 가축으로부터 분리된 세균을 대상으로 진행된 연 구는 매우 드물다. 특히 우리나라에서 사람과 가축에서 빈번하게 분리되는 세균 중 하나인 Proteus속을 대상으로 한 연구는 거의 없 다. Proteus속은 그람음성막대균으로 장내세균과에 속하며 오랫 동안 카테터를 삽입한 환자에게서 가장 빈번하게 요로감염을 일으 킨다. 뿐만 아니라 호흡기, 눈, 귀, 코, 피부, 목, 화상, 상처 등에 감염 을 일으키기도 하며 신생아에 뇌수막염, 축농증 및 골수염 등을 유 발한다[6]. 특히 P. mirabilis는 요로에 감염된 후 균혈증을 빈번하 게 일으키는데 미국에서는 노인환자의 경우에는 약 $50 \%$ 의 치사율 을 보인다고 보고된바 있다[7]. 본 연구에서는 충청지역에 위치한 일개의 대학병원 미생물검사실에서 분리된 P. mirabilis 균주와 같 은 지역에 위치한 일개의 양계장에서 사육되는 닭으로부터 분리된
P. mirabilis 균주를 대상으로 aminoglycoside계열 항균제 내성유 전자인 RMTases와 내성유전자 운반 및 확산에 중요한 역할을 하는 integron의 빈도 및 유전형을 조사하였다. 그리고 사람과 닭으로부 터 분리된 P. mirabilis 균주의 clonality를 비교·분석하였는데 이 연구결과는 충청지역에서 분리되는 P. mirabilis 균주의 내성기전 을 파악하는데 도움이 될 것으로 사료된다.

\section{재료 및 방법}

\section{1. 균주의 수집}

2014년 2월부터 2015년 2월까지 충청지역에 위치한 일개의 대 학병원에 의뢰된 임상검체로부터 분리된 P. mirabilis 18 균주와 같 은 지역 일개의 양계장에서 사육된 닭으로부터 분리된 P. mirabilis 20 균주를 대상으로 하였다. 항균제 내성에 상관없이 분리된 순서 대로 균주를 수집하였으며, 동일대상에서 반복하여 분리된 균주는 수집대상에서 제외하였다. 분리된 균주를 VITEK GNI card (bioMerieuxVitek Inc., Hazelwood, MO, USA)를 이용하여 생화 학적 방법으로 동정하였다.

\section{2. 항균제 감수성 시험}

분리된 P. mirabilis 38균주를 대상으로 CLSI 지침에 따라 amikacin, tobramycin, gentamicin, cefotaxime, ciprofloxacin, levofloxacin, 및 trimethoprim (Oxoid, Basingstoke, United Kingdom)에 대한 감수성을 Mueller-Hinton 한천(Difco, Cockeysville, $\mathrm{MD}$, USA)을 사용하여 디스크확산법으로 확인하였 다[8]. 정도관리를 위해서 Escherichia coli ATCC 25922를 동시에 시험하여 허용범위 내에 있는지를 확인하였다.

\section{3. 항균제 내성유전자 검출}

Aminoglycoside계열 항균제에 대한 내성유전자인 RMTases를 검출하기 위해 기존의 시발체(Table 1)를 사용하여 중합효소연쇄 반응을 수행하였다[9]. 대상균주를 brain heart infusion broth (Difco)에 접종하여 $37^{\circ} \mathrm{C}$ 에서 하룻밤 진탕배양 한 후 배양액으로 부터 DNA 추출시약(솔젠트, 대전, 한국)을 사용하여 chromosomal $\mathrm{DNA}$ 를 추출하였다. DNA 추출액 $(5 \mu \mathrm{L}), 10 \mathrm{mM} \mathrm{dNTP} \mathrm{mix} \mathrm{(0.5}$ $\mu \mathrm{L}), 10 \times$ Taq buffer $(2.5 \mu \mathrm{L}), 0.7 \mathrm{U}$ Taq DNA 중합효소(솔젠트), primer 각 $10 \mathrm{pmol}$ 및 증류수를 혼합하여 총부피 $25 \mu \mathrm{L}$ 의 반응용 액을 만들었다. Gene Amp PCR System 9600 (Perkin-Elmer Cetus Corp., Norwalk, CT, USA)으로 $95^{\circ} \mathrm{C}$ 에서 5 분간 반응시킨 후, $95^{\circ} \mathrm{C}$ 에서 20 초, $56^{\circ} \mathrm{C}$ 에서 30 초, $72^{\circ} \mathrm{C}$ 에서 40 초씩 30 회 증폭 반응 시키고, $72^{\circ} \mathrm{C}$ 에서 5 분간 연장반응 시켰다. 그리고 ethidium 
Table 1. Oligonucleotides used in this study for detection of antimicrobial resistant genes

\begin{tabular}{|c|c|c|c|c|}
\hline Reaction number & Primer & Sequence $\left(5^{\prime}-3^{\prime}\right)$ & Gene & Reference \\
\hline \multirow[t]{14}{*}{ Aminoglycoside resistant genes } & $\operatorname{armA}-\mathrm{F}$ & CAAATGGATAAGAATGATGTT & armA & [9] \\
\hline & $\operatorname{armA-R}$ & TTATTTCTGAAATCCACT & & \\
\hline & $r m t A-F$ & ATGAGCTTTGACGATGCCCTA & $r m t A$ & [9] \\
\hline & $r m t A-R$ & TCACTTATTCCTTTTTATCATG & & \\
\hline & $r m t B-F$ & ATGAACATCAACGATGCCCT & $r m t B$ & [9] \\
\hline & $r m t B-R$ & CCTTCTGATTGGCTTATCCA & & \\
\hline & $\mathrm{rmtC}-\mathrm{F}$ & CGAAGAAGTAACAGCCAAAG & rmtC & [9] \\
\hline & $r m t C-R$ & ATCCCAАСАТСТСТСССАСТ & & \\
\hline & $r m t D-F$ & CGGCACGCGATTGGGAAGC & $r m t D$ & [9] \\
\hline & $r m t D-R$ & CGGAAACGATGCGACGAT & & \\
\hline & $r m t E-F$ & ATGAATATTGATGAAATGGTTGC & $r m t E$ & [9] \\
\hline & $r m t E-R$ & TGATTGATTTCCTCCGTTTTTG & & \\
\hline & $\mathrm{rmtF}-\mathrm{F}$ & GCGATACAGAAAACCGAAGG & $r m t F$ & [9] \\
\hline & $r m t F-R$ & ACCAGTCGGCATAGTGCTTT & & \\
\hline \multirow[t]{6}{*}{ Integrons (for multiplex PCR) } & Int1 F & CAGTGGACATAAGCCTGTTC & int/1 & [10] \\
\hline & Int1 R & CCCGAGGCATAGACTGTA & & \\
\hline & Int2 F & GTAGCAAACGAGTGACGAAATG & int 12 & [10] \\
\hline & Int2 R & CACGGATATGCGACAAAAAGGT & & \\
\hline & Int3 F & GCCTCCGGCAGCGACTTTCAG & int/3 & {$[10]$} \\
\hline & Int3 R & ACGGATCTGCCAAACCTGACT & & \\
\hline \multirow[t]{2}{*}{ Integrons (for sequencing) } & Int1' F & GGCATCCAAGCAGCAAG & int/1 & [11] \\
\hline & Int1' R & AAGCAGACTTGACCTGA & & \\
\hline
\end{tabular}

Abbreviation: $F$, sense primer; $R$, antisense primer.

bromide가 포함된 1\% agarose gel에서 30분간 전기영동하여 각 $\mathrm{PCR}$ 생산물의 band를 확인한 후 $\mathrm{DNA}$ 추출시약(솔젠트)으로 증폭 산물을 분리하였다. 증폭산물의 염기서열분석에는 ABI PRISM 3730xl DNA analyzer (PE Applied Biosystems, Foster City, CA, USA)와 BigDye Terminator Cycle Sequencing Kit (PE Applied Biosystems)가 사용되었다.

\section{Integron의 유전자 카세트 분석}

1) Integron의 검출

Class 1, 2, 및 3에 속하는 integron을 검출하기 위해 기존의 시 발체(Table 1)를 사용하여 다중 중합효소연쇄반응을 수행하였다 [10]. 대상 균주를 brain heart infusion broth (Difco)에 접종하여 $37^{\circ} \mathrm{C}$ 에서 하룻밤 진탕배양 한 후 배양액으로부터 DNA 추출시약 (솔젠트)을 사용하여 염색체 DNA를 추출하였다. DNA 추출액(5 $\mu \mathrm{L}), 0.7 \mathrm{U}$ Taq DNA polymerase (솔젠트), $10 \mathrm{mM}$ dNTP mix (0.5 $\mu \mathrm{L}), 10 \times$ Taq buffer $(2.5 \mu \mathrm{L})$, primer 각 $10 \mathrm{pmol}$ 및 증류수를 혼 합하여 총 부피 $25 \mu \mathrm{L}$ 의 반응용액을 만들었다. Gene Amp PCR System 9600 (Perkin-Elmer Centus Corp.)으로 $95^{\circ} \mathrm{C}$ 에서 5 분간 반응시킨 후, $94^{\circ} \mathrm{C}$ 에서 1 분, $52^{\circ} \mathrm{C}$ 에서 1 분, $72^{\circ} \mathrm{C}$ 에서 1 분씩 30 회 증폭 반응시키고, $72^{\circ} \mathrm{C}$ 에서 5 분간 연장 반응시켰다. 각각의 $\mathrm{PCR}$ 생산물을 ethidium bromide가 포함된 1.5\% agarose gel에서 30 분간 전기영동하여 band를 확인하였다. PCR 생산물 band의 위치
가 약 $160 \mathrm{bp}, 788 \mathrm{bp}$, 및 $979 \mathrm{bp}$ 인 것을 각각 class 1, 2, 및 3 integron으로 간주하였다.

2) Class 1 integron의 유전자 카세트 유전형 확인

Class 1 integron내에 존재하는 유전자 카세트의 유전형을 확인 하기 위해 5' 보존영역과 3' 보존영역의 분절을 시발체(Table 1)로 하여 PCR을 수행하였다[11]. 다중 중합효소연쇄반응 때와 같은 조 성의 반응용액 $25 \mu \mathrm{L}$ 를 $95^{\circ} \mathrm{C}$ 에서 5 분간 반응시킨 후, $94^{\circ} \mathrm{C}$ 에서 1 분, $54^{\circ} \mathrm{C}$ 에서 1 분, $72^{\circ} \mathrm{C}$ 에서 4 분씩 30 회 증폭 반응시키고, $72^{\circ} \mathrm{C}$ 에 서 10 분간 연장 반응시켰다. 각각의 PCR 생산물을 ethidium bromide가 포함된 $1 \%$ agarose gel에서 30 분간 전기영동하여 band를 확인한 후 염기서열 분석을 수행하였다. 5' 보존영역과 3' 보존영역의 분절을 시발체로 하여 얻어진 각각의 PCR 생산물을 염 기서열 분석한 뒤, 말단 부분에서 다시 새로운 시발체를 디자인하 여 PCR을 수행하고 염기서열 분석을 하는 일련의 과정을 되풀이 하는 primer walking 방법으로 전체 염기서열을 분석하였다.

\section{Repetitive extragenic palindromic sequence-based $\mathrm{PCR}$ (REP-PCR)을 이용한 역학적 연관성 조사}

대상균주를 brain heart infusion broth (Difco)에 접종하여 $37^{\circ} \mathrm{C}$ 에서 하룻밤 진탕배양 한 후 배양액으로부터 DNA 추출시약 (솔젠트)을 사용하여 대상 균주의 염색체 $\mathrm{DNA}$ 를 추출하였다. 추출 
된 염색체 DNA를 주형 DNA로 사용하였고 시발체로는 REP1 (5'IIIGCGCCGICATCAGGC-3')과 REP2 (5'-ACGTCTTATCAGGCCTAC-3')로 명명된 장내세균의 반복 서열을 이용하였다[12]. 증폭반응은 DNA 추출액 $(5.0 \mu \mathrm{L}), 1.4 \mathrm{U} \mathrm{Taq}$ DNA polymerase (솔 젠트), $10 \mathrm{mM} \mathrm{dNTP} \mathrm{mix} \mathrm{(1.0 \mu L),} \mathrm{10 \times} \mathrm{Taq} \mathrm{buffer}(5.0 \mu \mathrm{L})$, primer 각 $20 \mathrm{pmol}$ 및 증류수를 혼합하여 $50 \mu \mathrm{L}$ 의 혼합액으로 시 행하였다. Gene Amp PCR System 9600 (Perkin-Elmer Centus Corp.)으로 $95^{\circ} \mathrm{C}$ 에서 5 분간 반응시킨 후, $95^{\circ} \mathrm{C}$ 에서 40 초, $42^{\circ} \mathrm{C}$ 에 서 1 분, $68^{\circ} \mathrm{C}$ 에서 7 분씩 35 회 증폭 반응시키고, $68^{\circ} \mathrm{C}$ 에서 15 분간 연장 반응시켰다. 증폭산물 $(10 \mu \mathrm{L})$ 은 ethidium bromide가 포함
된 2\% agarose gels에 전기영동 한 후 BioDoc-14 Imagingsystem (UVP, Cambridge, UK)을 이용하여 분석하였다. Band의 강도와 상관없이 band의 분자량과 개수로 각 균주를 비교하며, 두 개 이상 의 band 차이가 있으면 역학적 상관관계가 없는 것으로 판단하였 다[12].

\section{결 과}

\section{1. 항균제 감수성 양상}

시험기간 중 총 38 균주의 P. mirabilis가 분리되었는데 임상검

Table 2. Characterizations of $P$. mirabilis strains isolated from clinical specimens (H) and chickens (C)

\begin{tabular}{|c|c|c|c|c|c|c|c|c|c|c|}
\hline \multirow{2}{*}{ Isolates } & \multirow{2}{*}{$\begin{array}{l}\text { REP-PCR } \\
\text { patterns }\end{array}$} & \multicolumn{2}{|c|}{ Antimicrobial resistance determinants } & \multicolumn{7}{|c|}{ Antimicrobial susceptibilities } \\
\hline & & Class 1 integrons & 16S rRNAmethylases & AK & NN & $\mathrm{CN}$ & CTX & CIP & LEV & W \\
\hline $\mathrm{H} 1$ & $A$ & & & $\mathrm{~S}$ & S & S & $\mathrm{S}$ & $\mathrm{S}$ & S & $\mathrm{S}$ \\
\hline $\mathrm{H} 2$ & $\mathrm{~B}$ & & & $\mathrm{~S}$ & S & $\mathrm{R}$ & $\mathrm{R}$ & $\mathrm{S}$ & S & $S$ \\
\hline H3 & C & & & $S$ & $\mathrm{R}$ & $\mathrm{R}$ & $\mathrm{R}$ & $\mathrm{R}$ & I & $\mathrm{R}$ \\
\hline $\mathrm{H} 4$ & $\mathrm{D}$ & dfrA12-orff-aadA2 & armA & $\mathrm{R}$ & $\mathrm{R}$ & $\mathrm{R}$ & $\mathrm{R}$ & $\mathrm{S}$ & S & $\mathrm{R}$ \\
\hline H5 & $E$ & blapse-aadA2 & & S & S & $\mathrm{S}$ & $\mathrm{R}$ & $\mathrm{R}$ & $\mathrm{R}$ & $S$ \\
\hline $\mathrm{H} 6$ & $\mathrm{~F}$ & dfrA1-orfC & & $\mathrm{S}$ & S & $\mathrm{S}$ & $\mathrm{S}$ & । & $\mathrm{S}$ & $\mathrm{R}$ \\
\hline $\mathrm{H} 7$ & G & dfrA12-orff-aadA2 & $r m t B$ & $\mathrm{R}$ & $\mathrm{R}$ & $R$ & $\mathrm{R}$ & $\mathrm{S}$ & S & $\mathrm{R}$ \\
\hline H8 & $\mathrm{H}$ & dfrA12-orff-aadA2 & & S & S & S & $\mathrm{S}$ & $\mathrm{S}$ & S & $S$ \\
\hline H9 & I & dfrA12-orff-aadA2 & $\mathrm{rmtB}$ & $R$ & $R$ & $\mathrm{R}$ & $\mathrm{R}$ & $\mathrm{S}$ & S & $\mathrm{R}$ \\
\hline $\mathrm{H} 10$ & j & & & S & S & $\mathrm{S}$ & $\mathrm{S}$ & $\mathrm{S}$ & S & $\mathrm{S}$ \\
\hline $\mathrm{H} 11$ & K & blaPSE-aadA2 & $r m t B$ & $\mathrm{R}$ & $\mathrm{R}$ & $\mathrm{R}$ & $\mathrm{R}$ & $\mathrm{R}$ & $\mathrm{R}$ & $\mathrm{S}$ \\
\hline $\mathrm{H} 12$ & $\mathrm{~L}$ & & & $\mathrm{~S}$ & S & $\mathrm{R}$ & $\mathrm{R}$ & $\mathrm{R}$ & $R$ & $\mathrm{R}$ \\
\hline $\mathrm{H} 13$ & M & & & S & $\mathrm{R}$ & $\mathrm{R}$ & $\mathrm{S}$ & $\mathrm{S}$ & S & $S$ \\
\hline $\mathrm{H} 14$ & $\mathrm{~B}$ & est $X$ & $\mathrm{rmtB}$ & $\mathrm{R}$ & $\mathrm{R}$ & $\mathrm{R}$ & $\mathrm{R}$ & $\mathrm{R}$ & । & । \\
\hline $\mathrm{H} 15$ & $\mathrm{~N}$ & dfrA12-orff-aadA2 & $\mathrm{rmtB}$ & $\mathrm{R}$ & $\mathrm{R}$ & $\mathrm{R}$ & $\mathrm{R}$ & $\mathrm{R}$ & $\mathrm{R}$ & $R$ \\
\hline $\mathrm{H} 16$ & 0 & & & S & S & $\mathrm{S}$ & $\mathrm{S}$ & S & S & $\mathrm{S}$ \\
\hline $\mathrm{H} 17$ & $P$ & dfrA12-orff-aadA2 & $\operatorname{armA}$ & $\mathrm{R}$ & $\mathrm{R}$ & $\mathrm{R}$ & $\mathrm{R}$ & $\mathrm{R}$ & I & $\mathrm{R}$ \\
\hline $\mathrm{H} 18$ & $\mathrm{Q}$ & & & S & S & $R$ & $\mathrm{~S}$ & $\mathrm{~S}$ & S & $\mathrm{S}$ \\
\hline $\mathrm{C} 1$ & $\mathrm{a}$ & aacCA5-aadA7 & & $R$ & $R$ & $R$ & $\mathrm{~S}$ & 1 & S & $R$ \\
\hline $\mathrm{C} 2$ & $\mathrm{a}$ & $\operatorname{aac} C A 5-a a d A 7$ & & S & S & $\mathrm{R}$ & $\mathrm{S}$ & I & S & $\mathrm{R}$ \\
\hline $\mathrm{C3}$ & $a$ & $\operatorname{aac}(A 5-a a d A 7$ & & $S$ & $S$ & $\mathrm{R}$ & $\mathrm{S}$ & I & $S$ & $\mathrm{R}$ \\
\hline $\mathrm{C} 4$ & a & $\operatorname{aac} C A 5-a a d A 7$ & & S & S & $\mathrm{R}$ & $\mathrm{R}$ & I & S & $\mathrm{R}$ \\
\hline $\mathrm{C} 5$ & $\mathrm{~b}$ & & & S & I & S & $\mathrm{S}$ & $\mathrm{R}$ & S & $\mathrm{S}$ \\
\hline C6 & c & & & $S$ & $S$ & S & $\mathrm{S}$ & 1 & $S$ & $\mathrm{R}$ \\
\hline $\mathrm{C} 7$ & c & & & S & S & S & $\mathrm{S}$ & $\mathrm{S}$ & S & $\mathrm{S}$ \\
\hline C8 & $\mathrm{b}$ & & & S & S & S & $\mathrm{S}$ & 1 & S & $\mathrm{S}$ \\
\hline C9 & $d$ & aadA5-dfrA17 & & $\mathrm{R}$ & $\mathrm{R}$ & $\mathrm{R}$ & $\mathrm{S}$ & $\mathrm{R}$ & S & $\mathrm{R}$ \\
\hline $\mathrm{C} 10$ & $d$ & aadA5-dfrA17 & & $\mathrm{R}$ & $\mathrm{R}$ & $\mathrm{R}$ & $\mathrm{S}$ & $\mathrm{R}$ & $\mathrm{R}$ & $\mathrm{R}$ \\
\hline C11 & d & aadA5-dfrA17 & & S & $R$ & $R$ & $\mathrm{~S}$ & $\mathrm{R}$ & $R$ & $\mathrm{R}$ \\
\hline $\mathrm{C} 12$ & $d$ & aadA5-dfrA17 & & S & $\mathrm{R}$ & $\mathrm{R}$ & $\mathrm{S}$ & $\mathrm{R}$ & $\mathrm{R}$ & $\mathrm{R}$ \\
\hline C13 & $d$ & & & S & S & $\mathrm{S}$ & $\mathrm{S}$ & I & S & $\mathrm{R}$ \\
\hline $\mathrm{C} 14$ & d & aadA5-dfrA17 & & $S$ & । & $\mathrm{S}$ & $\mathrm{S}$ & $\mathrm{R}$ & $S$ & $\mathrm{R}$ \\
\hline C15 & $d$ & & & S & S & $\mathrm{S}$ & $\mathrm{S}$ & $\mathrm{R}$ & S & $\mathrm{R}$ \\
\hline C16 & e & aadA2-linF & & S & S & $\mathrm{S}$ & $\mathrm{S}$ & $\mathrm{R}$ & $\mathrm{R}$ & $\mathrm{R}$ \\
\hline $\mathrm{C} 17$ & c & dfrA32-ereA-aadA2 & & $S$ & $\mathrm{R}$ & $\mathrm{S}$ & 1 & $\mathrm{~S}$ & $S$ & $\mathrm{R}$ \\
\hline C18 & c & aadA2-linF & & $\mathrm{R}$ & S & $\mathrm{S}$ & $\mathrm{S}$ & $\mathrm{R}$ & $\mathrm{R}$ & $\mathrm{R}$ \\
\hline C19 & c & & & $\mathrm{S}$ & S & $\mathrm{S}$ & $\mathrm{S}$ & $\mathrm{S}$ & S & $\mathrm{S}$ \\
\hline $\mathrm{C} 20$ & c & dfrA32-ereA-aadA2 & & S & $\mathrm{R}$ & $\mathrm{S}$ & I & 1 & S & $\mathrm{R}$ \\
\hline
\end{tabular}

Abbreviation: REP-PCR, repetitive extragenic palindromic sequence-based PCR; AK, amikacin; NN, tobramycin; CN, gentamicin; CTX, cefotaxime; CIP, ciprofloxacin; LEV, levofloxacin; W, trimethoprim; S, susceptible; I, intermediate resistant; R, resistant. 
Table 3. Antimicrobial susceptibilities of $P$. mirabilis strains isolated from clinical specimens and chickens

\begin{tabular}{|c|c|c|c|c|c|c|c|c|c|}
\hline \multirow{3}{*}{ Agent } & \multicolumn{9}{|c|}{ Numbers (\%) of isolates } \\
\hline & \multicolumn{3}{|c|}{$\begin{array}{l}\text { Isolates from clinical specimens } \\
\qquad(\mathrm{n}=18)\end{array}$} & \multicolumn{3}{|c|}{$\begin{array}{l}\text { Isolates from chickens } \\
\qquad(\mathrm{n}=20)\end{array}$} & \multicolumn{3}{|c|}{$\begin{array}{l}\text { Total isolates } \\
\quad(n=38)\end{array}$} \\
\hline & $S$ & I & $\mathrm{R}$ & $\mathrm{S}$ & । & $\mathrm{R}$ & $\mathrm{S}$ & । & $\mathrm{R}$ \\
\hline AK & $11(61.1)$ & $0(0.0)$ & 7 (38.9) & $16(80.0)$ & $0(0.0)$ & $4(20.0)$ & $27(71.1)$ & $0(0.0)$ & $11(28.9)$ \\
\hline NN & $9(50.0)$ & $0(0.0)$ & $9(50.0)$ & $11(55.0)$ & $2(10.0)$ & $7(35.0)$ & $20(52.6)$ & $2(5.3)$ & $16(42.1)$ \\
\hline $\mathrm{CN}$ & $6(33.3)$ & $0(0.0)$ & $12(66.7)$ & $12(60.0)$ & $0(0.0)$ & $8(40.0)$ & $18(47.4)$ & $0(0.0)$ & $20(52.6)$ \\
\hline CTX & $7(38.9)$ & $0(0.0)$ & $11(61.1)$ & $17(85.0)$ & $2(10.0)$ & $1(5.0)$ & $24(63.2)$ & $2(5.3)$ & $12(31.6)$ \\
\hline CIP & $10(55.6)$ & $1(5.6)$ & $7(38.9)$ & $3(15.0)$ & $8(40.0)$ & $9(45.0)$ & $13(34.2)$ & $9(23.7)$ & $16(42.1)$ \\
\hline LEV & $11(61.1)$ & $3(16.7)$ & $4(22.2)$ & $15(75.0)$ & $0(0.0)$ & $5(25.0)$ & $26(68.4)$ & $3(7.9)$ & $9(23.7)$ \\
\hline W & $9(50.0)$ & $1(5.6)$ & $8(44.4)$ & $4(20.0)$ & $0(0.0)$ & $16(80.0)$ & $13(34.2)$ & $1(2.6)$ & $24(63.2)$ \\
\hline
\end{tabular}

Abbreviation: AK, amikacin; NN, tobramycin; CN, gentamicin; CTX, cefotaxime; CIP, ciprofloxacin; LEV, levofloxacin; W, trimethoprim; S, susceptible; I, intermediate resistant; $\mathrm{R}$, resistant.

체로부터 분리된 P. mirabilis 가 18 균주였고 닭으로부터 분리된 $P$. mirabilis가 20균주였다(Table 2). 이 균주들을 대상으로 항균제 감수성시험을 한 결과 amikacin에 대한 감수성이 $71.1 \%$ 로 가장 높 은 것으로 나타났고 levofloxacin에 대한 감수성이 $68.4 \%$ 로 그 다 음으로 높은 것으로 나타났다(Table 3). 한편 본 연구에서 사용된 7 종류의 항균제에 대한 감수성이 닭으로부터 분리된 균주가 임상검 체로부터 분리된 균주에 비해 전반적으로 높은 것으로 나타났으나 ciprofloxacin 및 trimethoprim에 대한 감수성은 오히려 닭으로 부터 분리된 균주가 더 높은 것으로 나타났다.

\section{2. 내성유전자검출}

총 38균주의 P. mirabilis를 대상으로 RMTases 유전자(armA, $r m t A, r m t B, r m t C, r m t D, r m t E$, 및 $r m t F)$ 의 빈도를 조사하기 위해 중합효소연쇄반응 및 염기서열분석을 수행한 결과 임상검체로부 터 분리된 7균주(18.4\%)가 RMTases 유전자를 가지고 있음이 확인 되었다. RMTases 유전자 중 $r m t B$ 유전자를 포함하는 균주가 5균 주로 가장 많았으며 $\operatorname{arm} A$ 유전자도 2균주에서 검출되었다. 반면 닭으로부터 분리된 균주에서는 RMTases 유전자가 하나도 검출되 지 않았다.

\section{Integrons의 검출}

총 38균주의 P. mirabilis를 대상으로 integron을 검출하기 위 해 다중중합효소연쇄반응을 수행한 결과 23 균주(60.5\%)에서 class 1 integron에 해당하는 약 $160 \mathrm{bp}$ 크기의 PCR 산물이 얻어졌 다. Class 1 integron이 검출된 23균주 중 10균주는 임상검체로부 터, 그리고 13균주는 닭으로부터 분리된 균주였다. 반면 class 2 와 class 3 integron에 해당하는 약 $788 \mathrm{bp}$ 와 $979 \mathrm{bp}$ 크기의 PCR 산 물은 본 연구에서는 검출되지 않았다.
임상검체로부터 분리된 class 1 integron을 포함하고 있는 10 균 주와 닭으로부터 분리된 class 1 integron을 포함하고 있는 13균주 를 대상으로 유전자 카세트 유전형 분석을 위한 PCR과 염기서열 분석을 수행하였다. 총 8 종류의 서로 다른 class 1 integron이 분석 되었는데, 임상검체로부터 분리된 균주에서 4종류의 class 1 integron이 그리고 닭으로부터 분리된 균주에서 4종류의 class 1 integron이 확인되었다(Table 2). 확인된 8종류의 class 1 integrons 중 2종류의 integrons를 제외한 나머지 6종류의 integrons은 모두 aminoglycoside 내성에 관련된 유전자카세트 $(\mathrm{aad} A 2$, aadA5, $a a d A 7$, 및 $a a c C A 5$ )를 포함하고 있었다. 본 연구에서 확인된 class 1 integrons는 그 외에도 $\beta$-lactmase 유전자인 blapse, trimethoprim 내성에 관여하는 유전자인 dfrA12, dfrA17및 dfrA32, lincosamides 내성에 관여하는 유전자인 linF 및 erythromycin 내 성에 관여하는 유전자인 ereA 등을 유전자 카세트로 포함하고 있 었다.

\section{REP-PCR을 이용한 역학적 연관성 조사}

시험기간 중 분리된 총 38균주의 P. mirabilis 균주를 대상으로 $\mathrm{REP}-\mathrm{PCR}$ 을 수행한 결과 임상검체로부터 분리된 균주와 닭으로부 터 분리된 균주가 서로 같은 band 패턴을 보인 경우는 하나도 없었 다(Fig. 1). 한편, 임상검체로부터 분리된 균주 중 2균주를 제외한 16 균주는 모두 각기 서로 다른 band 패턴을 보였으나 닭으로부터 분리된 균주는 총 5 종류(a e형)의 band 패턴을 보이며 그룹을 형 성하였다. 그 중에서 가장 빈번하게 나타난 band 패턴은 $\mathrm{d}$ 형(7균 주)이었으며 그 다음으로 c형(6균주)과 a형(4균주) band 패턴이 빈 번하였다. 


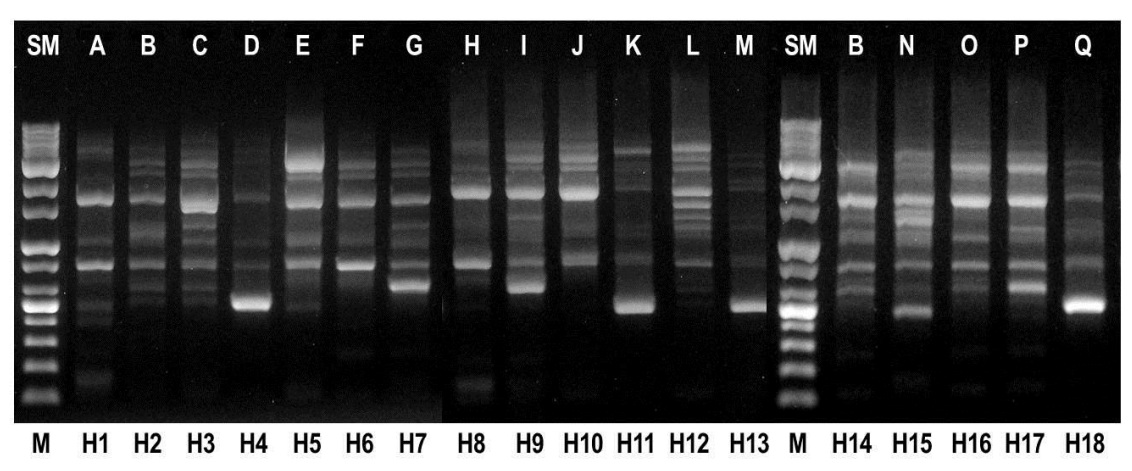

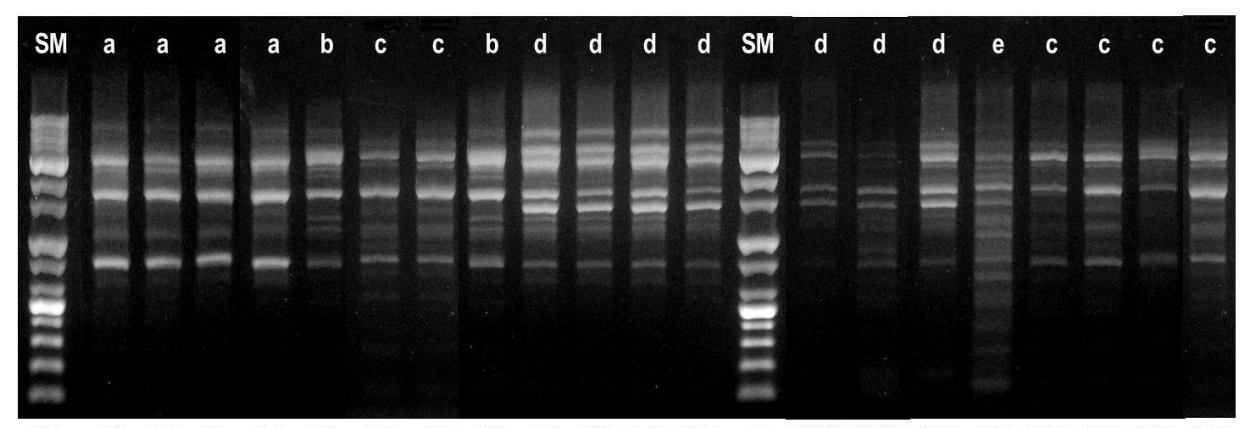

$\begin{array}{lllllllllllllllllllllllllllll}M & \text { C1 } & \text { C2 } & \text { C3 } & \text { C4 } & \text { C5 } & \text { C6 } & \text { C7 } & \text { C8 } & \text { C9 } & \text { C10 } & \text { C11 } & \text { C12 } & \text { M } & \text { C13 } & \text { C14 } & \text { C15 } & \text { C16 } & \text { C17 } & \text { C18 } & \text { C19 } & \text { C2O }\end{array}$
Fig. 1. Repetitive element sequencebased (REP)-PCR patterns of genomic DNA from $P$. mirabilis strains isolated from clinical specimens $(\mathrm{H})$ and Chickens (C). Lane SM is $1 \mathrm{~kb}$ DNA size marker.

\section{고 찰}

최근 항균제의 지속적인 사용으로 인해 가축으로부터 내성세균 의 분리빈도가 증가되고 있으며 사람에게 병을 일으킬 수 있는 $P$. mirabilis, E. coli, Salmonella spp., 및 Enterobacterspp. 등을 포 함하는 장내세균들이 빈번하게 가금류로부터 분리되고 있다[13]. 그러나 대부분의 연구자들은 임상검체로부터 분리된 균주들의 항 균제 내성기전 분석에 연구의 초점을 맞추고 있다. 본 연구에서는 임상검체로부터 분리된 P. mirabilis 균주와 가금류 중 가장 많은 수를 차지하는 닭으로부터 분리된 P. mirabilis 균주를 대상으로 항 균제 감수성 양상과 aminoglycoside계열 항균제에 대한 내성기전 그리고 clonality를 비교분석 하였다.

Aminoglycoside계열 항균제에 대한 내성기전을 분석하기 위 해 총 38균주의 P. mirabilis를 대상으로 RMTases 유전자를 조사 하였는데 임상검체로부터 분리된 7균주에서만 RMTases 유전자가 검출되었고 닭으로부터 분리된 균주에서는 RMTase 유전자가 확 인되지 않았다. 임상검로부터 분리된 7균주(18.4\%)가 RMTase 유 전자를 포함하고 있는 것으로 나타났으며 그 중 $r m t B$ 유전를 포함 하는 균주가 5 균주였다. 이 결과는 이전에 국내에서 임상검체로부 터 분리된 대장균 및 폐렴막대균을 대상으로 한 연구에서 $35.9 \%$ 에 해당하는 균주들이 $r m t B$ 유전자를 포함하고 있다고 한 보고에 비 해 많이 낮은 수치였다[14,15]. 아마도 본 연구에서는 임상검체로 부터 분리된 균주 뿐만 아니라 닭으로부터 분리된 균주를 대상으로 조사하였기 때문에 RMTase 유전자의 검출빈도가 낮았던 것으로
사료된다. RMTase는 장내세균, Pseudomonas aeruginosa, 및 Acinetobacterspp.를 포함한 그람음성 병원성세균에 존재하면서 이 세균들이 현재 임상에서 사용되고 있는 대부분의 aminoglycoside계열 항균제에 내성을 나타내게 하는 주된 원인이 되고 있다 [16]. 본 연구에서도 총 38균주의 P. mirabilis를 대상으로 시행된 aminoglycoside계열 항균제 감수성시험 결과 amikacin, tobramycin, 및 gentamicin에 대한 내성율이 각각 $28.9 \%, 42.1 \%$, 및 $52.6 \%$ 로 나타난 반면 RMTase 유전자를 포함하고 있는 7균주는 3 종류의 aminoglycoside계열 항균제에 모두 내성을 나타냈다 (Table 2). 이 결과는 RMTase 유전자가 P. mirabilis 균주가 aminoglycoside계열 항균제에 내성을 나타내는데 중요한 원인으 로 작용했음을 시사한다.

한편, 항균제 내성유전자의 획득 및 확산에 중요한 역할을 하는 것으로 알려져 있는 integron은 integrase의 구조에 따라 class가 분류되는데 가장 빈번하게 검출되고 있으며 항균제 내성과 관련이 있는 것은 class 1 integron이다[17]. 중국에서 분리된 Proteus spp.의 경우 63.0\%가 class 1 integron을 포함하고 있었으며, 국내 에서도 54.5\%의 대장균이 class 1 integron을 포함하고 있음이 확 인된 바 있다[17,18]. 본 연구에서도 총 38균주 중 23 균주 $(60.5 \%)$ 가 class 1 integron을 가지고 있는 것으로 나타나 이전의 보고들과 유사한 결과를 보였다. 검출된 class 1 integron의 유전자 카세트는 총 8종류였는데 임상검로부터 분리된 균주가 가장 많이 포함하고 있 는 것으로 나타난 유전자 카세트는 dfrA12-orfF-aadA2이었던 반 면 닭으로부터 분리된 균주가 가장 많이 포함하고 있었던 유전자 카 
세트는 aadA5-dfrA17이었다. 유전자 카세트 dfrA12-orff-aadA2 는 중국에서 분리된 Proteus spp.에서도 가장 빈번하였으며 dfrA32-ereA1-aadA2및 dfrA1-orfC 유전자 카세트 또한 이전에 보고된 바 있다[17]. 이번 연구에서 분석된 총 8개의 integron중 6 종류의 integron은 모두 aminoglycoside 내성에 관련된 유전자 카세트(aadA2, aadA5, aadA7, 및 $a a c C A 5)$ 를 포함하고 있었는데 aadA2, aadA5, 및 aadA7 유전자 카세트는 streptomycin 및 spectinomycin에 대한 내성에, 그리고 $a a c C A 5$ 유전자 카세트는 gentamicin에 대한 내성에 관여하는 것으로 알려져 있다[18,19]. 그 외에도 trimethoprim 내성에 관여하는 유전자인 dfrA12, dfrA17및 dfrA32가 class 1 integron내에 유전자 카세트로 존재 하고 있음이 확인되었는데, $d f A A$ 유전자 카세트를 가지고 있는 17 균주 중 16균주가 trimethoprim에 내성을 나타냈다. 이 결과는 $d f r A$ 유전자가 P. mirabilis 균주가 trimethoprim에 내성을 나타 내는데 중요한 역할을 했음을 의미한다.

덧붙여 임상검체로부터 분리된 P. mirabilis 균주와 닭으로부터 분리된 P. mirabilis 균주의 역학적 관련성을 조사하기 위해 REP-PCR을 수행한 결과 임상검체로부터 분리된 균주와 닭으로부 터 분리된 균주는 서로 다른 clone에서 유래되었음이 확인되었고 역학적으로 크게 관련성이 없는 것으로 나타났다(Fig. 1). 그러나 닭으로부터 분리된 균주의 경우에는 band 패턴에 따라 그룹이 형 성되었고 빈번하게 나타나는 clone들이 있었는데 이는 닭들 사이 에서 일부 균주가 확산되어 전파되었음을 의미한다. 또한 대부분의 균주가 band 패턴에 따라 포함하고 있는 유전자 카세트가 다른 것 으로 나타났는데, a형 band 패턴을 나타낸 4균주는 aacCA5$a a d A 7$ 유전자 카세트를 그리고 d형 band 패턴을 나타낸 5균주는 aadA5-dfrA17유전자 카세트를 가지고 있음이 확인되었다. 또한 dfrA32-ereA-aadA2 유전자 카세트는 c형 band 패턴을 보인 2균 주에서만 확인되었다(Table 2).

본 연구에서는 충청지역 대학병원 임상검체에서 분리된 $P$. mirabilis 균주와 닭으로부터 분리된 P. mirabilis 균주를 대상으로 aminoglycoside 내성유전자, integron 빈도 및 유전형을 조사하 였다. Aminoglycoside계열 항균제에 내성을 나타내는데 중요한 역할을 하는 RMTase는 임상검체로부터 분리된 P. mirabilis 균주 에서만 높은 빈도로 검출된 반면 항균제 내성유전자의 확산에 중요 한 역할을 하는 class 1 integron은 임상검체 및 닭으로부터 유래한 균주 모두에서 높은 빈도로 검출되었다. 이 결과는 내성세균의 확 산 및 다제내성 세균의 출현이 병원환경 뿐 만 아니라 가축을 사육 하는 축사환경에서도 일어날 수 있음을 의미하며 이를 방지하기 위 해서는 병원환경 뿐만 아니라 축사환경을 대상으로 지속적인 내성 유전자의 모니터링과 감염관리가 필요할 것으로 사료된다.

\section{요 약}

최근 사람과 가축에 항균제의 과도한 사용으로 감염병을 일으키 는 병원성 세균들의 항균제 내성이 증가하고 있다. 본 연구에서는 $\mathrm{PCR}$ 과 염기서열분석법을 이용하여 충청지역 일개의 대학병원에 의뢰된 임상검체와 같은 지역에서 사육된 닭으로부터 분리된 $P$. mirabilis 균주를 대상으로 16S ribosomal RNA methyltransferase (RMTase) 유전자와 integron을 조사하였다. 또한 Repetitive extragenic palindromic sequence-based PCR (REP-PCR) 을 이용하여 P. mirabilis 균주들의 역학적 연관성 조사하였다. 총 38균주의 P. mirabilis 중에서 임상검체로부터 분리된 7균주 (18.4\%)만이 RMTases 유전자를 가지고 있었는데 이들은 모두 amikacin, tobramycin, 및 gentamicin에 내성을 나타냈다. 또한 대상균주 중 23균주(60.5\%)가 class 1 integron을 가지고 있는 것 으로 나타났으며 class 2 및 class 3 integron은 검출되지 않았다. 본 연구에서 확인된 integrons에는 aminoglycoside 내성유전자 (aadA2, aadA5, aadA7, 및 aacCA5), $\beta$-lactmam 내성유전자 (blapsE), erythromycin 내성유전자(ereA), lincosamides 내성유 전자(linF), 및 trimethoprim 내성유전자(dfrA12, dfrA17 및 dfrA32)등이 유전자 카세트로 포함되어 있었다. 본 연구결과 RMTase 유전자는 임상검체로부터 분리된 P. mirabilis 균주에만 확산되어 있었던 반면 class 1 integrons는 임상검체와 닭으로부터 분리된 P. mirabilis 균주에 광범위하게 확산되어 있음을 확인할 수 있었다. 게다가 닭으로부터 분리된 균주 중에는 동일한 REP-PCR 밴드패턴을 보인 균주들이 있었는데 이는 닭들 사이에서 $P$. mirabilis 균주가 수평확산 되었음을 의미한다. P. mirabilis 균주 에서 항균제 내성유전자의 확산을 막기 위해서는 내성유전자 지속 적인 모니터링과 감시가 필요할 것으로 사료된다.

Acknowledgements: 이 연구는 2016년도 극동대학교 교내연구 비 지원에 의해 수행된 것임(FEU2016R08).

Funding: None

Conflict of interest: None

\section{References}

1. Levy SB. Antibiotic resistance: an ecological imbalance. Ciba Found Symp. 1997;207:1-9.

2. Rho H, Shin B, Lee O, Choi YH, Rho J, Lee J. Antibiotic resistance profile of bacterial isolates from animal farming aquatic environments and meats in a peri-urban community in Daejeon, Korea. J Environ Monit. 2012;14:1616-1621.

3. Garneau-Tsodikova S, Labby KJ. Mechanisms of resistance to aminoglycoside antibiotics: overview and perspectives. 
Medchemcomm. 2016;7:11-27.

4. Park YJ. Aminoglycoside resistance in gram-negative bacilli. Korean J Clin Microbiol. 2009;12:57-61.

5. Wei Q, Hu Q, Li S, Lu H, Chen G, Shen B, et al. A novel functional class 2 integron in clinical Proteus mirabilis isolates. J Antimicrob Chemother. 2014;69:973-976.

6. Schaffer JN, Pearson MM. Proteus mirabilis and urinary tract infections. Microbiol Spectr. 2015;3:1-66.

7. Sader HS, Flamm RK, Jones RN. Frequency of occurrence and antimicrobial susceptibility of Gram-negative bacteremia isolates in patients with urinary tract infection: results from United States and European hospitals (2009-2011). J Chemother. 2014;26:133-138.

8. CLSI. Performance standards for antimicrobial susceptibility testing; sixteenth informational supplement. CLSI document M100-S20. Wayne, PA: Clinical and Laboratory Standards Institute;2010, p52-53.

9. Hidalgo L, Hopkins KL, Gutierrez B, Ovejero CM, Shukla S, Douthwaite $S$, et al. Association of the novel aminoglycoside resistance determinant $\mathrm{RmtF}$ with NDM carbapenemase in Enterobacteriaceae isolated in India and the UK. J Antimicrob Chemother. 2013;68:1543-1550.

10. Dillon B, Thomas L, Mohmand G, Zelynski A, Iredell J. Multiplex PCR for screening of integrons in bacterial lysates. J Microbiol Methods. 2005;62:221-232.

11. Lévesque C, Piché L, Larose C, Roy PH. PCR mapping of integrons reveals several novel combinations of resistance genes. Antimicrob Agents Chemother.1995;39:185-191.

12. Bou G, Cerveró G, Domínguez MA, Quereda C, MartínezBeltrán J. PCR-based DNA fingerprinting (REP-PCR, AP-PCR) and pulsed-field gel electrophoresis characterization of a nosocomial outbreak caused by imipenem- and meropenem-resistant Acinetobacter baumannii. Clin Microbiol Infect. 2000;6: 635-643.

13. Nahar A, Siddiquee M, Nahar S, Anwar KS, Islam S. Multidrug resistant-Proteus Mirabilis isolated from chicken droppings in commercial poultry farms: bio-security concern and emerging public health threat in Bangladesh. J Biosafety Health Educ. 2014:2:1-5.

14. Galani I, Souli M, Panagea T, Poulakou G, Kanellakopoulou K, Giamarellou H. Prevalence of 16S rRNA methylase genes in Enterobacteriaceae isolates from a Greek university hospital. Clin Microbiol Infect. 2012;18:52-54.

15. Shin SY, Kwon KC, Park J W, Song JH, Ko YH, Sung JY, et al. Characteristics of aac $\left(6^{\prime}\right)-I b-c r$ gene in extended-spectrum $\beta$-lactamase-producing Escherichia coli and Klebsiella pneumoniae isolated from Chungnam area. Korean J Lab Med. 2009; 29:541-550.

16. Doi Y, Arakawa Y. 16S ribosomal RNA methylation: emerging resistance mechanism against aminoglycosides. Clin Infect Dis. 2007;45:88-94.

17. Wei Q1, Hu Q, Li S, Lu H, Chen G, Shen B, et al. A novel functional class 2 integron in clinical Proteus mirabilis isolates. J Antimicrob Chemother. 2014;69:973-976.

18. Dessie HK, Bae DH, Lee YJ. Characterization of integrons and their cassettes in Escherichia coli and Salmonella isolates from poultry in Korea. Poult Sci. 2013;92:3036-3043.

19. Sung JY, Byeon YG. Characterizations of class 1 integrons in Proteus mirabilis isolated from chickens at Chungcheong province. Korean J Clin Lab Sci. 2015;47:65-70. 